\title{
'A horse-race is the same all the world over': the cultural context of horse racing in Native North America
}

\begin{abstract}
Native American horse racing has received little scholarly attention. Focusing on the Great Plains and the Southwest, this paper argues that, far from being a diversion, it was a major focus for male competition for status and prestige. Since these concerns were at least as strong externally as internally, horse racing (and racehorse acquisition) formed part of a continuum of agonistic activities that also encompassed warfare. Moreover, the significance of races for the standing of individuals, men's societies, and tribal groups led to widespread use of protective medicines for enhancing equine performance and combating interference from opponents. Gambling formed part of this set of practices that collectively warrant describing Native American horse racing as a form of what Johan Huizinga termed 'sacred play'. For these reasons it encountered strong opposition from Euro-American authorities during the reservation era. Conversely, the persistence of Native American horse racing traditions via rodeo and Indian Relay racing attests to the enduring importance of the values they express. Opportunities exist for extending this preliminary assessment into a broader comparative study of Indigenous horse racing traditions across the post-1492 world.
\end{abstract}

KEYWORDS Native Americans; horse races; competition; war; resistance

\section{'One of the Most Exciting Amusements'}

In the 1830s one of the great artists of the American West, George Catlin, remarked of the Mandan (Rųwą' ka·ki) ${ }^{1}$ people of what is now North Dakota that, 'Horse-racing here, as in all more enlightened communities, is one of the most exciting amusements, and one of the most extravagant modes of gambling' (Figure 1). ${ }^{2} \mathrm{He}$ went on to say that, 'a horse-race is the same all the world over,' a conclusion roundly condemned (though without explanation) as 'erroneous' by the twentieth-century ethnographer John Ewers in his landmark monograph The Horse in Blackfoot Indian Culture. That not only the Mandan, but also many other Native Americans, engaged in horse racing is well established. However, with but a few recent exceptions there has been remarkably little discussion of the topic since Ewers wrote about it over 60 years ago. ${ }^{4}$ Intended as an initial step toward exploring Indigenous horse racing practices not only in North America but also in other parts of the world to which horses were (re-)introduced as a consequence of the so-called 'Columbian Exchange', 5 this paper thus offers a fresh assessment of Catlin's remark.

Its principal focus falls upon two of the historic centres of Native equestrianism in North America, the Great Plains and the Southwest (Figure 2), and it begins by giving a sense of how horse races were organized and the form that they took. Merely to assert, however, that horse racing was something 'learned from the Spanish' is not particularly helpful, ${ }^{6}$ even in the unlikely event that it were true. Instead, to understand horse racing's importance for Native American societies it must be situated within the broader context of Indigenous gaming practices. This, in turn, identifies one of the key questions to be addressed: how far was horse racing part of a continuum with other games and contests and to what extent did it therefore involve 
ritual, ceremonial, and other elements, rather than being simply a diversion or an opportunity to win wagers. In other words, was horse racing an example of what Johan Huizinga termed 'sacred play'?

The paper also explores two related concerns. First, why were attempts made to suppress horse racing in the aftermath of Euro-American conquest of the Plains and the Southwest and the confinement of Native peoples to reservations? Second, how far do nineteenth-century traditions of horse racing still persist in contemporary Native American practice and the broader culture of the North American West? Both topics involve placing horse racing within a wider context of resistance to colonization and forced acculturation. On all three counts, Native American racing on horseback is an eminently anthropological topic, one that arguably merits more attention from historians and other social scientists than it has hitherto received.

By way of background recall that while horses evolved in North America they also became extinct there through a combination of the environmental changes marking the transition to post-glacial climates and human hunting at the end of the Pleistocene, some 11,000 years ago. ${ }^{8}$ Horses were reintroduced by Cortés in 1519 , were in Native hands within a generation, and had spread north of the Río Grande before the Spanish began settling New Mexico in 1598. That spread, it should be noted, had nothing to do with horses left behind by the entrada of Francisco Coronado in 1540-42 (they were not, and only two of Coronado's $\sim 600$ horses were mares in any event). Nor did it have much to do with the Pueblo Revolt of 1680 that temporarily expelled the Spanish from the Southwest: Utes (Nú·čiu), Navajos (Diné), and Apaches (Ndé) all had horses long before that. Instead, through processes that were almost entirely Native, rather than European, controlled, horses began moving north onto the Plains and into the mountains areas to their west early in the seventeenth century and continued to do so thereafter, transforming the lives of all those who adopted them in ways that were still ongoing in the mid-1800s. ${ }^{9}$

\section{Racing Horses in Native North America}

How did Native Americans race the horses they acquired? One of the earliest references is that of David Thompson, who wrote of the Piegan (Pi-kániwa), a Blackfoot (Niitsítapi) group, around 1800 that they raced horses 'not in the regular manner,' but by betting on who could first run down a deer or kill the most bison at a time. ${ }^{10}$ As Ewers notes, however, Thompson probably simply failed to see horse races of a more conventional kind, since oral traditions suggest that they were being practised decades before this, perhaps almost as soon as the Piegan acquired horses around $1725 .^{11}$ Races were held between tribal groups, and in at least some cases truces might be arranged between otherwise hostile communities specifically so that they could take place. ${ }^{12}$ Additionally, they also took place within the same tribe, with different Blackfoot warrior societies, for example, frequently competing against each other, each society having previously identified its own fastest horses in private trials. ${ }^{13}$ Similar practices are recorded among the Gros Ventre or Atsina (Haaninin), ${ }^{14}$ as well as other nations. Often, larger camps at which people could aggregate because of seasonal bonanzas from summer bison hunts ${ }^{15}$ or, on the Columbia Plateau, salmon runs and camas root harvests ${ }^{16}$ provided the context for racing competitions. In one instance in October 1839 as many as 4,000 people from several tribes are said to have converged to race at a location near the modern city of Denver in Colorado. ${ }^{17}$ 
Most commonly, two horses were raced against each other over a level course measuring some 3-6 km in length. ${ }^{18}$ Both Blackfoot races on the Northern Plains and Navajo contests in the Southwest took this form, ${ }^{19}$ although races between several competitors at a time were far from unknown. Additionally, among some groups horses were raced over shorter distances of around $500 \mathrm{~m},{ }^{20}$ or a longer course might be subdivided so that races of different lengths could be run along it. ${ }^{21}$ Navajo, Kiowa (Ka'igwu), and Blackfoot, among others, typically selected horses thought to be closely matched in speed, something that intensified the associated betting. ${ }^{22}$ Where there was insufficient level ground, races might be run around a hill, or, among the Northern Shoshone (Nimi) a stick, ${ }^{23}$ and back. A pair of judges, one from each side, was commonly used to ensure fair play among the members of the Blackfoot confederacy and in their competitions with neighbouring peoples, ${ }^{24}$ something Catlin himself depicted in a painting of a Mandan horse race now in the Smithsonian American Art Museum (Figure 1). ${ }^{25}$ Blackfoot and Comanche (Nimini) might also station observers along the course to make sure that the race was run fairly and to provide feedback to spectators, ${ }^{26}$ while among the Ute races might be repeated to fully establish the superiority of one horse over another. ${ }^{27}$ Finishing lines consisted of a furrow scraped in the earth, a pair of piled rocks, or a tree. ${ }^{28}$ The latter was a practice of the Comanche, who also engaged in two other kinds of race, both of which emphasized their agility on horseback. In one, riders rushed at a pole set on forks some $1.8 \mathrm{~m}$ above the ground, the winner being the first to touch it without stopping too soon, hitting it, or being thrown from his horse as the latter passed below. Alternatively, strips of hide were fastened 2-3 m apart on the ground and riders raced their horses at full speed toward them from some $200 \mathrm{~m}$ away, jumping between the strips before turning around and returning to the start: a horse that did not get all its feet beyond the first strip, or that put just one beyond the second, was disqualified even if it had the better time. ${ }^{29}$

To win all these events demanded considerable skill, as well as horses of high quality. Among some Northern Plains groups (the Hidatsa (Hirá ca), the Blackfoot, and the Lakota) colts intended for use as racehorses might be trained from the age of about one year and were frequently castrated to make them faster or prevent them from tiring easily. ${ }^{30}$ The efficacy of slitting a horse's nostrils to make it long-winded while running may be doubted, but was nevertheless widely practised, for example by Navajo, Comanche, and Lakota. ${ }^{31}$ Harness equipment was reduced to the bare minimum: along with a whip, a single twist of rawhide rope sufficed as a bridle for Hidatsa, Blackfoot, and Comanche riders, among others. ${ }^{32}$ Saddles, if used, were of the same flat type employed when hunting, i.e. pads of soft skin stuffed with antelope hair. ${ }^{33}$ However, riding bareback was also common, with jockeys wearing the minimal possible amount of clothing - or none at all, as Catlin discovered to his embarrassment when challenged to take part in a race at one Hidatsa village! ${ }^{34}$ Riders did not, it should be noted, have to be the horses' owners: among Blackfoot, for instance, they were typically the latter's younger male relatives, while in similar vein Comanche explicitly preferred 'little men'. ${ }^{35}$

Betting was a fundamental part of Native American horse races, their 'principal mode of gambling' as George Catlin described it for the Comanche, ${ }^{36}$ who wagered horses, blankets, and cattle. ${ }^{37}$ Navajo, on the other hand, bet 'buckskins, saddlebags, blankets, and bundles' (of sacred objects), ${ }^{38}$ while at Blackfoot races horses, guns, bison robes, 
blankets, and food were all common stakes, with men and women typically placing separate wagers among themselves. Saddles, bows and arrows, and even tipi lodges could also be wagered, although contrary to one early report referring to the Blackfoot wives were not. ${ }^{39}$ Losers who protested at their loss were likely to be publicly humiliated and might forfeit the trust of their fellows. ${ }^{40}$ As well as providing a means by which desirable possessions, including trade goods and booty captured in war, could circulate within the community, betting readily served as an expression of community solidarity in contexts in which riders from one group competed against those of another. ${ }^{41}$

\section{More than Sport: Ritual and War}

What I have described so far is not all that dissimilar to the horse races with which nineteenth-century Euro-American observers might have been familiar. However, in other respects Native American horse races differed considerably from contemporary European norms. Most obvious, perhaps, was the widespread employment of protective medicines believed to enhance a horse's performance or guard against the evil intentions of competitors. Cheyenne (TsisTsisTsas), for example, rubbed the dried leaves of arrowhead (Sagittaria cuneata) onto their racehorses as a charm, but also employed skunkbush (Rhus trilobata) to prevent them from tiring and to bewitch the horse ahead so that it would exhaust itself. A third but unidentified plant, vanó?ova, might be scattered behind the lead jockey to slow down his opponents. ${ }^{42}$ Several other botanical stimulants are recorded for a wide range of Plains groups, either to make horses run faster, to increase their stamina, or to revive them after a race (Table 1). ${ }^{43}$ Moreover, in at least some instances such stimulants needed to be applied in a ceremonial manner by specialists with appropriate ritual knowledge. ${ }^{44}$

Fearing witchcraft, Navajo and Apache also made extensive use of medicines, including applying 'coyote pollen' (powdered dust from where a coyote had stood) to the base of the horse's tail, sprinkling the horse's body with a solution of camote-demonte (Peteria scoparia), providing infusions of spruce (Picea sp.), juniper (Juniperus sp.), ponderosa pine (Pinus ponderosa), or White River coraldrops (Besseya (previously Veronica) plantaginea), and rubbing herbs into the horse's feet. ${ }^{45}$ Conversely, they also knew how to make a horse lose a race: whether by applying medicines brewed from sacred datura (Datura metaloides), jimsonweed (D. stramonium), or poison ivy (Toxicodendron radicans) to the legs or via the mouth, or by burying something that had touched the horse (dirt from its tracks, saliva, sweat, hair, manure, urine etc.) in a place where someone had died or been buried and then singing over it for evil to come to the animal. Recovering the items buried by the witch could counteract this, as could the use of other plant-based medicines. ${ }^{46}$

Blackfoot likewise used plant-based ritual medicines to influence races, tying them to a horse's tail, spraying them onto the rider's quirt, or holding them in his mouth to forestall being overtaken by another rider. ${ }^{47}$ They also sought to prevent horse medicine men (i.e. individuals with specialist ritual knowledge of horses) from approaching the horses to be raced for fear that they might use their powers to cause an animal to tire or falter. ${ }^{48}$ To get round this, Blackfoot horse medicine men could provide a jockey with a willow stick to which horse medicine had been applied with instructions to touch the competing horse with it during the race. Alternatively, they might paint a rock with medicine and then touch a rawhide horse with the rock so that 
it would leave the course or buck. ${ }^{49}$ At least among the Comanche the medicines used to influence a race's outcome were tabooed to women and they had to be removed from the horse by washing it in a creek immediately after the race. ${ }^{50}$

At one level practices such as these might be considered akin to cheating, and certainly the latter was not unknown. One could, for example, enter a horse that looked good, but was actually very slow, wagering against it in order to win the bet, or conversely enter one that looked weak, but was actually very fast. ${ }^{51}$ Alternatively, one could run one's own horse (or that of one's opponent if one could gain access to it) all night long so that it would be too tired to compete effectively the following day, or deliberately hold a horse back during the race itself. At least among the Navajo, practices such as these were treated more as a good joke than as a moral issue; being found out merely required one to acknowledge one's actions with good grace so that a rematch could be rearranged or wagers returned. ${ }^{52}$

Nevertheless, attempting to influence the outcome of a horse race by invoking supernatural powers or using what might be called magical aids immediately places Native American horse racing within a much broader context of competitive play. That context was one in which gambling - 'a central aspect of indigenous culture ${ }^{, 53}$ - constituted another means of trying to predict, and thus control, the future so that creation should continue to unfold as it had previously. ${ }^{54}$ Along with warfare, many competitive games and contests on the Plains also formed part of a continuum of agonistic activities in which individuals sought to prove their superiority and excellence vis-à-vis others. ${ }^{55}$ While war and raiding provided the most prestigious avenue for securing this (albeit in an external context), games and races offered 'an acceptable substitute for displaying prowess between members of the same tribe', ${ }^{56}$ especially for younger males. Pursuing prestige through these means was one of the principal ways by which men sought to maintain and enhance their self-esteem and status while simultaneously striving to make a name for themselves that would long be remembered. 'Game involvement [could thus] serve as a primary means of socialization for engagement in warfare', which was simply an extension of gaming redirected at the extra-tribal level. ${ }^{57}$

Clearly, then, horse racing occupied a more serious position in many Native American societies than might initially seem to be the case. As rule-governed contests emphasizing the display and demonstration of physical prowess and skill, horse races afforded individuals and the men's societies and ethnic groups to which they belonged opportunities for ascertaining, challenging, confirming, and enhancing their social standing. ${ }^{58}$ The fact that all possible means, including the manipulation of supernatural powers, should be deployed in pursuit of this is wholly consistent with the general spiritual connections of gambling and gaming across many North American societies. ${ }^{59}$ Partaking of the qualities of what Huizinga called 'sacred play, ${ }^{60}$ i.e. contests and rituals in which cosmic order is epitomized and maintained, horse racing - like foot races, other games, and counting coup on an enemy - was thus far from being a purely secular activity. ${ }^{61}$ Instead, it was both secular and sacred, ${ }^{62}$ requiring strategies that were themselves both practical and mystical. ${ }^{63}$ Moreover, since the stakes involved extended beyond material possessions to include the pride, honour, and status of the individuals and groups competing, it is all the more understandable how disputes over the outcomes of horse races could sometimes precipitate violence of the kind that erupted after a dead heat between Piegan and 
Kutenai (Ktunaxa) jockeys in $1878,{ }^{64}$ or even the all-out warfare that broke out over the winnings from races between previously co-operating Cree ( $\mathrm{Ne} \cdot h$ hiyawak) and Blackfoot camps in the spring of $1841 .^{65}$

Conceptually, the link between horse racing and warfare is underlined further by the way in which Blackfoot men's societies challenged each other to a horse race: someone who had already been successful in war would dress himself and his horse in exactly the same way as when he had counted coup on an enemy, ride to the lodge of the leader of the rival society, sing his personal war song, shoot at the lodge's poles, and issue his challenge. Hearing this, the other society's leader would rush out and fire his gun in the air, boasting that, 'I killed an enemy, knocked him down and scalped him. You are not going to scalp me'. ${ }^{66}$ Men's behaviour immediately before the start of the race reinforced the association: members of the competing societies reenacted their coups on past enemies against each other, for example by knocking their rivals down and pretending to scalp them. ${ }^{67}$

To win races horses needed both stamina and speed (Figure 3). On the nineteenthcentury Plains men sought precisely the same qualities for the 'buffalo runners' they trained to get in close to a running bison so that the rider could shoot to kill at close range after which the horse would swerve away to avoid injury. ${ }^{68}$ The swiftness, endurance, courage, and agility that this demanded were precisely the same qualities prized among the horses that a man rode in war. In many instances, indeed, the horses used to race, hunt, and fight were one and the same, just as among the Blackfoot and the Navajo the medicines used to ensure success in all three activities were also frequently identical. ${ }^{69}$ In this vein, while recalling a bison hunt in the Yellowstone area around 1869, the Hidatsa elder Buffalo-Bird-Woman remembered that a woman named Otter had once ridden Ita-takic (White-Face), a gelding used both in horse races and for hunting bison; ${ }^{70}$ her brother, Wolf-Chief, made the same point with respect to another horse. ${ }^{71}$ Blackfoot racehorses, on the other hand, were used as buffalo runners after they had reached the age of nine, i.e. when they were no longer considered at their very best for racing. But whether employed sequentially or contemporaneously, such important animals, like a man's favourite war pony, received special treatment from many Plains peoples in so far as they were used minimally, if at all, as pack animals or for ordinary riding. ${ }^{72}$

Being 'the most valuable horse' that a man could own, ${ }^{73}$ racehorses were highly desired, and even today may be offered in payment for valued items, such as the right to use a particular kind of painted lodge design, among some tribes, for example the Blackfoot. ${ }^{74}$ Typically, owners kept them close to home, even picketed at the tipi door. $^{75}$ Men might undertake expeditions with the specific intention of trying to acquire such animals ${ }^{76}$ and their capture on a raid brought great prestige, something widely recognized in the systems of graded honours accorded successful warrior exploits. ${ }^{77}$ The Piegan elder Mountain Chief, for example, used the capture of a sorrel racehorse from the Flathead (Séliš) as a key event to remember the year $1853 / 54,{ }^{78}$ while another, Saahkómaapi, interviewed by David Thompson late in the eighteenth century, considered horse theft to be far more impressive than actions on the battlefield precisely because of the greater risks that it entailed. ${ }^{79}$ Acquiring already trained racehorses by taking them from others was nevertheless itself an act of war, part of a pattern in which enemies made horse raids but horse raids in turn made enemies. ${ }^{80}$ In this respect, just as much as because winning races conferred prestige 
and social standing or because supernatural powers were invoked to achieve both goals, Native American horse racing and horse races were far more than a simple contest of skill between individuals and their mounts.

\section{'Pernicious Practices'}

With these points in mind it becomes easier to understand why, in the aftermath of the wars, epidemics, and ecological destruction that forced Native Americans onto reservations in the late $1800 \mathrm{~s}$, Euro-American authorities took such pains to suppress horse racing and other 'pernicious practices'. ${ }^{81}$ Widely recognized as being among 'their chief amusements', ${ }^{82}$ Native Americans' love of horse racing was considered by both missionaries and government officials to be heathen, potentially subversive, and inimical to the instillation of the Protestant work ethic that would supposedly transform equestrian hunters into model proto-capitalist, Christianized farmers and ranchers. ${ }^{83}$ The traditional emphasis on betting at horse races incurred particular ire, ${ }^{84}$ especially where horse races formed part of the fairs promoted by Office of Indian Affairs agents. As early as 1877, for example, gambling and horse racing faced suppression on the Flathead Reservation in Montana, ${ }^{85}$ though in what is now western Oklahoma the Southern Arapaho (Inuna-Ina) were able to continue racing by making it an important part of annual Independence Day celebrations at their Fort Reno reservation until this was forcibly ceded away in $1891 .{ }^{86}$ Over two decades later, the Indian Office's Commissioner, Cato Sells, could still be found arguing that, 'If, to the Indians, the paramount features [of such events] are to dance and wager on horse races, the quicker the fairs are terminated the better'. ${ }^{87}$ Unsurprisingly, however, his suggestion that horse races should be replaced by 'slow mule races' met with little enthusiasm, and two years later he was again demanding that horse racing be replaced at Kiowa and Comanche get-togethers by more acceptable athletic contests, foot races, and baseball. ${ }^{88}$

Similar efforts were made on the Northern Plains where, from the late 1890s, the Oglala Lakota living on the Pine Ridge Reservation in South Dakota were encouraged to take part in fairs that were also shared with their Euro-American neighbours. The Office of Indian Affairs promoted these events in order to encourage agricultural production, but for the Oglala their primary function was to emphasize traditional kinship ties and tribal unity. Horse races at such gatherings were initially repressed where possible, but from 1917 increasingly tolerated in the form of relay races within a rodeo format that could provide 'a positive point of contact for whites and Indians, ${ }^{89}$ Indeed, for the Oglala, as for other Native American groups like the Crow ${ }^{90}$ rodeo's attractiveness lay precisely in its being a cultural innovation that allowed them to perpetuate treasured ways of doing things, including coming together 'as a people...in ways that local whites would accept'. when the Office of Indian Affairs lost interest in promoting the Oglala Fair, rodeo (and horse racing) became one of the main emphases of the fairs organized entirely by the Oglala themselves, ${ }^{92}$ just as they were at similar events among the Crow and other tribes. $^{93}$

\section{The Persistence of Native American Horse Racing Traditions}

Rodeo's growing popularity in the Inter-War period among both Native Americans and Euro-Americans has been noted by several writers (Figure 4). ${ }^{94}$ Ian Dyck, in 
particular, has emphasized the strength of Indigenous contributions to its development, ${ }^{95}$ and at least among Blackfoot competitors these include a continuing belief in the efficacy of traditional medicines for affecting the outcome of competitions. ${ }^{96}$ For them, as for the Oglala, the Comanche, and the Kiowa, ${ }^{97}$ rodeo has provided one highly effective way of retaining traditionally significant cultural practices in a very different world: 'to gather; to wager; to give away horses, cattle, and other gifts; to reaffirm the status of individual horsemen; and to retain certain elements of their own equestrian heritage'. ${ }^{98}$ It is not, however, unique. Horse racing has also survived in other contexts, such as Navajo ceremonial dances (where it is accompanied by much betting) and in annual relay races among the Jicarilla Apache (Haísndayı̌n). ${ }^{99}$ But it is perhaps the relatively recent rise to prominence of Indian Relay racing that underlines more clearly than anything else the persistence of horse racing patterns inherited from pre-reservation times.

Developing at powwows and county fairs in the 1980s, ${ }^{100}$ Indian Relay was originally called 'pony express' after the mid-nineteenth-century United States postal service. It is now restricted to Native American participants, follows standardized rules, and was regulated between 2013 and 2017 by the Professional Indian Horse Racing Association (PIHRA) before coming under the supervision of its successor, the Horse Nations Indian Relay Council (HNIRC). ${ }^{101}$ Still considered, with good reason, an extreme sport, Indian Relay involves a team of three horses, a jockey who leaps on to them, a 'mugger' who catches the newly dismounted horse, and two handlers who hold the other animals. An almost exclusively male competition (though women may own, or even train, the horses, and in some instances have now begun to race them) ${ }^{102}$ Indian Relay is run on a half-mile $(800 \mathrm{~m})$ oval track using specially (re)trained Thoroughbreds or Quarter Horses, often animals with prior experience of conventional flat racing. The jockey starts on or next to the first horse, races round the track, jumps off, and changes on to the second, and then the third, horse, ideally without colliding with the horses or riders of the up to six other teams taking part in the same event. Covering some $2.5 \mathrm{~km}$ in total, the whole race lasts just a few minutes. ${ }^{103}$

Today, HNIRC brings together almost 50 relay teams from over 15 Native American nations. Multiple events are held each summer across the Northern Plains and the Plateau, with HNIRC publishing a regular online magazine about its activities, maintaining an informative website, and also organizing more conventional horse races, including events for women and children. ${ }^{104}$ Of particular interest in the context of this paper is the way in which several features of Indian Relay racing replicate aspects of nineteenth-century Native American horse races. Jockeys use only very simple bridles and ride without saddles and on occasion employ the 'wheel and run' start used in some nineteenth-century races. ${ }^{105}$ Additionally, symbolic designs that may bring good luck are often painted on both horses ${ }^{106}$ and riders, traditional medicines are used to promote their speed and endurance, ${ }^{107}$ and the principal reward for winning a race is not necessarily money, but rather prestige. ${ }^{108}$ In at least some cases, moreover, those participating draw explicitly on longstanding family traditions of horse racing. ${ }^{109}$ As Amelia-Roisin Seifert perceptively remarks, this is a sport 'based around a modern day "warrior" ethos of masculine bravado, skill and competition, anchored by a love of horses'. ${ }^{110}$ In all these respects, as well as in its emphasis on minimizing the use of harness equipment and its invocation of supernatural aid, Indian Relay underlines the enduring nature of Native American 
horse racing traditions even while its participants employ the resources of Western veterinary and nutritional medicine, sports science, and long-distance transportation and communicate their exploits via social media. Importantly, several documentary films relating to Indian Relay have now started to provide an Indigenous voice on these same traditions and to draw the attention of non-Native audiences to them and to their history. ${ }^{111}$

\section{Racing Futures}

In an initial effort to assess how far George Catlin was correct to write that "a horserace is the same all the world over", ${ }^{112}$ this paper has focused on two regions of Native North America, the Great Plains and the Southwest. It has argued that rather than being practised simply as a diversion, Native American horse racing in these areas formed part of a cultural context that emphasized and exalted competitions between men for the purpose of asserting, confirming, and enhancing their status and prestige in relation to those of others. Supporting Catlin's comment, and thus taking issue with John Ewers' condemnation of it, ${ }^{113}$ the other papers in this issue confirm that such social and political concerns were far from absent in cultural contexts as different as Classical Greece and Rome, the European Renaissance, and early modern Britain. ${ }^{114}$ In Native North America, however, those concerns were at least as strong externally as they were internally, meaning that horse racing formed part of a continuum of agonistic activities that encompassed warfare, and could even precipitate it where different tribal groups disputed the outcomes of races. Moreover, because the best racehorses were typically also those preferred for hunting bison or riding into war, there was every incentive to acquire them — pre-trained — by raiding other tribes, an act that itself won honour and encouraged yet further raids. The significance attached to race outcomes in terms of the wagers made on them and their consequences for the standing of the individuals, men's societies, and tribal groups taking part also meant that reliance was frequently placed on supernatural aid: protective medicines for enhancing a horse's performance were widely used, witchcraft and the interference of ritual specialists belonging to the opposite side widely feared. It was for these reasons, and not just because of concerns about Native 'idleness', that horse racing encountered such opposition from colonial authorities during the reservation era. Conversely, the persistence of Native American horse racing traditions, most conspicuously via the development of rodeo and, more recently, Indian Relay racing, attests to their enduring importance for Indigenous people and the continuing significance of the values that they express and celebrate.

Future investigations of the points raised here would certainly benefit from exploring the relevant ethnographic and historical literature in greater depth while simultaneously launching a more detailed investigation of the horse's continuing significance for Native North American communities. This topic continues to remain curiously under-explored by anthropologists, although the work of Amelia-Roisin Seifert and Brandi Bethke, like that of Elizabeth Atwood Lawrence a generation ago, shows that it is not wholly neglected. ${ }^{115}$ Attention should be particularly directed toward a more detailed consideration of the diversity of horse racing practices between regions of North America and among different Indigenous groups in order to avoid homogenizing all Native American societies in the image of just a few. Research into differences in the religious and political associations that horse racing 
held (and still hold) and in the responses made to attempts to suppress races after Euro-American conquest may be especially productive.

At the same time, we must remember that North America was not the only region to which horses returned, or were introduced, as a result of Europe's post-Columbian expansion. There is thus also much scope for a broader comparative study of how Indigenous horse racing traditions emerged in many different parts of the world. ${ }^{116}$ Such investigations could, among others, call upon the Mapuche of Chile and Argentina, the Aónik'enk of Patagonia, the Wayúu of Colombia, the Mocoví of northern Argentina, the Māori of New Zealand, and the involvement of Aboriginal Australians in developing an antipodean form of rodeo. ${ }^{117}$ In short, just as the horse's encounter with Indigenous peoples post-1492 demands a global approach, so too does any analysis of how, when, why, and under what circumstances Native forms of horse racing emerged, resisted attempts at suppression, and persisted. Collectively, such studies should allow us to understand better how far George Catlin was or was not correct when he asserted that, 'a horse-race is the same all the world over'. ${ }^{118}$

\section{Declaration of interest}

The author reported no potential conflict of interest.

\section{Notes}

${ }^{1}$ The commonly accepted English names for the various Native American groups mentioned are employed in the text, but the relevant self-designation follows in brackets after their first usage where this differs.

${ }^{2}$ George Catlin, Letters and Notes on the Manners, Customs and Conditions of North American Indians, Volume I (New York: Dover, 1973), 143. Catlin's work, and especially his paintings, provides important documentation of Native American societies on the Great Plains at a time (1830-8) when Native equestrianism was at its height and effective control of the region by the United States had yet to be imposed. Nevertheless, while often sympathetic to those whom he described and depicted, it must be acknowledged that Catlin shared with many of his contemporaries a tendency to idolize those whom he saw as 'noble savages' and - quite wrongly - a 'vanishing race' (Laurence Hauptmann, and George Hamell, 'George Catlin: The Iroquois Origins of his Indian Portrait Gallery,' New York History: Quarterly Journal of the New York State Historical Association 84 (2003), 123-51; Robert Lewis, 'Wild American Savages and the Civilized English: Catlin's Indian Gallery and the Shows of London,' European Journal of American Studies 3(1) (2008): document 6.

${ }^{3}$ John Ewers, The Horse in the Blackfoot Indian Culture with Comparative Material from Other Western Tribes (Washington DC: Smithsonian Institution, 1955), 235.

${ }^{4}$ Though for recent efforts to the contrary see, Brandi Bethke, 'Dog Days to Horse Days: Evaluating the Rise of Nomadic Pastoralism among the Blackfoot' (PhD diss., School of Anthropology, University of Arizona, 2016); Amelia-Roisin Seifert, 'An Introduction to Contemporary Native American Horse Culture: Notes from the Northwest Plateau,' in The Meaning of Horses: Biosocial Encounters, ed. Dona Lee Davis and Anita Maurstad (London: Routledge, 2016), 147-63. 
${ }^{5}$ Alfred Crosby, The Columbian Exchange: Biological and Cultural Consequences of 1492 (Westport NJ: Greenwood Publishing, 1972).

${ }^{6}$ As stated by Alyce Cheska, 'Sport as Ethnic Boundary Maintenance: A Case of the American Indian', International Review for the Sociology of Sport 19 (1984): 241-57.

${ }^{7}$ Johan Huizinga, Homo Ludens: A Study of the Play-Element in Culture (London: Routledge and Kegan Paul, 1950).

${ }^{8}$ Jack Broughton, and Elic Weitzel, 'Population reconstructions for humans and megafauna suggest mixed causes for North American Pleistocene extinctions', Nature Communications 9 (2018): article 5441.

${ }^{9}$ This process has been most recently reviewed by Peter Mitchell, Horse Nations: The Worldwide Impact of the Horse on Indigenous Societies Post-1492 (Oxford: Oxford University Press, 2015). New research suggests, however, that horses spread north even faster than previously thought, reaching as far as Wyoming, for example, by the mid-1600s. See, Cassidee Thornhill, 'Equus ferus caballus during the Protohistoric in Wyoming: Looking for the Horse in the Archaeological Record' (MA diss., Department of Anthropology, University of Wyoming, 2016).

10 David Thompson, David Thompson's Narrative of His Explorations in Western America, 1784-1812, (Toronto: Champlain Society, 1916, ed. J.B. Tyrell), 359.

${ }^{11}$ Ewers, The Horse in the Blackfoot Indian Culture, 227-8.

12 Philip Stepney, and David Goa, The Scriver Collection (Edmonton: Provincial Museum of Alberta, 1990), 39.

${ }^{13}$ Ewers, The Horse in the Blackfoot Indian Culture, 228, 230.

${ }^{14}$ Regina Flannery, and John Cooper, 'Social Mechanisms in Gros Ventre Gambling', Southwestern Journal of Anthropology 2 (1946): 391-419.

${ }^{15}$ Ewers, The Horse in the Blackfoot Indian Culture, 227-8.

${ }^{16}$ Ruthann Knudson, 'Fish, Roots, Game, and Trade in the Columbia Plateau', Journal of Forestry 78 (1980): 542-56; Helen Schuster, 'Yakima and Neighboring Groups', in Handbook of North American Indians Volume 12 Plateau, ed. Deward Walker (Washington DC: Smithsonian Institution, 1998), 327-51; Eugene Hunn, and David French, 'Western Columbia River Sahaptins', in Handbook of North American Indians Volume 12 Plateau, ed. Deward Walker (Washington DC: Smithsonian Institution, 1998), 378-94.

${ }^{17}$ William Butler, 'Indian Horse Racing in Colorado', Southwestern Lore 84 (2018): 29-34, who notes the existence of at least two further horse racing locations in Colorado.

${ }^{18}$ For example, see the description given by Henry Boller, Among the Indians: The Far West, 1858-1866 (Philadelphia: T.E. Zell, 1868), 66-7.

19 Janet Cliff, 'Playing with Games: Cheating in Navajo and Euro-American Gambling', Western Folklore 49 (1990): 221-5; Ewers, The Horse in the Blackfoot Indian Culture, 230.

${ }^{20}$ For examples of such shorter races see William Hamilton, 'A Trading Expedition Among the Indians in 1858', Contributions of the Montana Historical Society 3 (1900): 33-123 for one between Piegan and Crow (Apsáaloke) competitors, and James Schultz, My Life as an Indian (Greenwich: Fawcett Publications, 1907), 134-6 for another between Piegan and Kutenai (Ktunaxa) jockeys.

${ }^{21}$ Butler, 'Indian Horse Racing in Colorado', 310.

${ }^{22}$ Cliff, 'Playing with Games'; Ewers, The Horse in the Blackfoot Indian Culture, 229

${ }^{23}$ Robert Lowie, 'The Northern Shoshone', Anthropological Papers of the American Museum of Natural History 2 (1909): 165-306. 
${ }^{24}$ Ewers, The Horse in the Blackfoot Indian Culture, 229, 231, 233, 235.

${ }^{25}$ Horseracing on a Course Behind the Mandan Village, 1832-1833, oil on canvas, $49.7 \times 70.0 \mathrm{~cm}$, Smithsonian American Art Museum, Washington DC, https://americanart.si.edu/artwork/horseracing-course-behind-mandan-village-4109 (accessed January 22, 2019).

${ }^{26}$ Ewers, The Horse in the Blackfoot Indian Culture, 231; Thomas Kavanagh, ed., Comanche Ethnography, Lincoln: University of Nebraska Press, 2008), 135.

27 James Russell, 'Conditions and Customs of Present-Day Ute in Colorado', Colorado Magazine 6 (1927): 104-12.

28 Richard Dodge, Our Wild Indians: Thirty-Three Years' Personal Experience Among the Red Man of the Great West (Hartford, CT: A.D. Worthington, 1883), 340; Ewers, The Horse in the Blackfoot Indian Culture, 230.

${ }^{29}$ Dodge, Our Wild Indians, 340.

${ }^{30}$ Gilbert Wilson, 'The Horse and the Dog in Hidatsa Culture', Anthropological Papers of the American Museum of Natural History 25 (1924): 125-311; Ewers, The Horse in the Blackfoot Indian Culture, 228; Royal Hassrick, The Sioux: Life and Customs of a Warrior Society (Norman: University of Oklahoma Press, 1964).

${ }^{31}$ LaVerne Clark, They Sang for Horses: The Impact of the Horse on Navajo and Apache Folklore (Boulder: University Press of Colorado, 2001), 184.

${ }^{32}$ Wilson, The Horse and the Dog in Hidatsa Culture', 183; Ewers, The Horse in the Blackfoot Indian Culture, 230; Kavanagh, Comanche Ethnography, 135.

${ }^{33}$ Wilson, The Horse and the Dog in Hidatsa Culture', 190.

${ }^{34}$ Demetri Shimkin, 'Introduction of the Horse', in Handbook of North American Indians Volume 11 Great Basin, ed. Warren L. d'Azevedo (Washington, DC: Smithsonian Institution, 1986), 517-24; Catlin, Letters and Notes, 197-8.

35 Ewers, The Horse in the Blackfoot Indian Culture, 230; Kavanagh, Comanche Ethnography, 135.

${ }^{36}$ George Catlin, Letters and Notes on the Manners, Customs and Conditions of North American Indians, Volume II (New York: Dover, 1973), 65.

${ }^{37}$ Kavanagh, Comanche Ethnography, 135.

${ }^{38}$ Clyde Kluckholn, Willard Hill, and Lucy Wales Kluckholn, Navajo Material Culture (Cambridge, MA: Belknap Press, 1971), 388.

${ }^{39}$ Edward Wilson, 'Report on the Blackfoot Tribes', Report of the British Association for the Advancement of Science 57 (1887): 183-200. Wilson's report is refuted by Ewers, The Horse in the Blackfoot Indian Culture, 230-1).

${ }^{40}$ Ewers, The Horse in the Blackfoot Indian Culture, 232; Kavanagh, Comanche Ethnography, 135.

${ }^{41}$ Richard Ford 1983, 'Inter-Indian Exchange in the Southwest', in Handbook of North American Indians Volume 10 Southwest, ed. Alfonso Ortiz (Washington, DC: Smithsonian Institution, 1983), 311-22; Theodore Stern, 'Cayuse, Umatilla and Walla Walla', in Handbook of North American Indians Volume 12 Plateau, ed. Deward Walker (Washington, DC: Smithsonian Institution, 1998), 395-419.

42 Jeffrey Hart, 'The Ethnobotany of the Northern Cheyenne Indians of Montana', Journal of Ethnopharmacology 4 (1981): 1-55.

${ }^{43}$ For discussion of one such instance, see George Morgan, "'Sugar Bowls" (Clematis hirsutissima): A Horse Restorative of the Nez Perce', Journal of Ethnopharmacology 4 (1981): 117-20.

44 Frank Dobie, 'Indian Horses and Horsemanship,' Southwest Review 35 (1960): 265-75. 
${ }^{45}$ Clark, They Sang for Horses, 184-5.

${ }^{46}$ Ibid. 185-6.

47 John Hellson, and Morgan Gadd, Ethnobotany of the Blackfoot Indians (Ottawa:

National Museum of Canada, 1974).

${ }^{48}$ Ewers, The Horse in the Blackfoot Indian Culture, 230.

${ }^{49}$ Ibid. 272.

${ }^{50}$ Kavanagh, Comanche Ethnography, 135.

${ }^{51}$ Ewers, The Horse in the Blackfoot Indian Culture, 232, provides an example of the latter situation among the Piegan.

${ }^{52}$ Cliff, 'Playing with Games'. As she discusses, Euro-American failure to appreciate Native views on cheating was at the root of the massacre at Fort Fauntleroy, New Mexico, in 1861 when at least 12 Navajo were killed. The incident arose after a Navajo rider lost control of his horse because his reins had been cut, leaving his EuroAmerican competitor the winner. The soldiers present first denied that their compatriot had cheated, then refused to return their ill-gotten winnings, and finally used force to prevent one Navajo from entering the fort to retrieve them.

${ }^{53}$ Stewart Culin, Games of the North American Indians (Washington, DC: Bureau of American Ethnology, 1907), 14.

54 Yale Belanger, 'Towards an Innovative Understanding of North American Indigenous Gaming in Historical Perspective', in First Nations Gambling in Canada, ed. Yale Belanger (Winnipeg: University of Manitoba Press, 2011), 10-34

55 John Loy, and Graham Hesketh, 'Competitive Play on the Plains: An Analysis of Games and Warfare among Native American Warrior Societies, 1800-1850, in The Future of Play Theory: A Multidisciplinary Inquiry, ed. Anthony Pellegrini (Albany: State University of New York Press, 1995), 73-106.

${ }^{56}$ Robert Morford, and Stanley Clark, 'The agon motif', Exercise and Sport Sciences Reviews 4 (1976): 164.

${ }^{57}$ Loy and Hesketh, 'Competitive Play on the Plains', 78

${ }^{58}$ Loy and Hesketh, 'Competitive Play on the Plains', 98-9.

${ }^{59}$ Belanger, 'Towards an Innovative Understanding of North American Indigenous Gaming in Historical Perspective', 20-2.

${ }^{60}$ Johan Huizinga, Homo Ludens.

${ }^{61}$ As recounted by Clark, They Sang for Horses, 31-2, among the Navajo and Apache even the gods raced horses in myths that recounted the creation of horses and other animals. Both peoples, for example, tell how the elder of the Hero Twins borrowed a horse from Father Sun in order to defeat his opponent in a race around the world. In another myth, Clark, They Sang for Horses, 23-4, details how a race is held around the horizon to restore harmony among the animals, but the god Black Begochiddy cheats by changing the appearance of his mount, a donkey, so that with narrower feet and a shorter tail it can run faster than all the others.

${ }^{62}$ Virginia McGowan, Lois Frank, Gary Nixon, and Misty Grimshaw, 'Sacred and Secular Play in Gambling among Blackfoot Peoples of Southwest Alberta, in Culture and the Gambling Phenomenon: Proceedings of the 11th National Association for Gambling Studies Conference, Sydney, Australia, 2001, ed. Alex Blaszczynski (Alphington: National Association for Gambling Studies, 2001), 241-55.

${ }^{63}$ Culin, Games of the North American Indians, 807, makes a similar point with reference to the Crow.

${ }^{64}$ Schultz, My Life as an Indian, 134-6. 
${ }^{65}$ George Colpitts, 'Peace, War, and Climate Change on the Northern Plains: Bison Hunting in the Neutral Hills During the Mild Winters of 1830-34', Canadian Journal of History 50 (2015): 420-41.

${ }^{66}$ Ewers, The Horse in the Blackfoot Indian Culture, 229.

${ }^{67}$ Ibid. 231.

${ }^{68}$ Mitchell, Horse Nations, 156-7.

${ }^{69}$ Ewers, The Horse in the Blackfoot Indian Culture, 270-5; Clark, They Sang, 186

${ }^{70}$ Wilson, 'The Horse and the Dog in Hidatsa Culture', 280.

${ }^{71}$ Ibid. 299, 305.

72 Ibid. 310; Ewers, The Horse in the Blackfoot Indian Culture, 228; Hassrick, The Sioux, 162.

${ }^{73}$ Ewers, The Horse in the Blackfoot Indian Culture, 228.

${ }^{74}$ Adolf Hungrywolf, The Blackfoot Papers - Volume Two: Pikunni Ceremonial Life (Skookumchuk: The Good Medicine Cultural Foundation, 2006), 352.

75 Thomas Biolsi, 'Ecological and Cultural Factors in Plains Indian Warfare', in Warfare, Culture and Environment, ed. R. Brian Ferguson (Orlando, FL: Academic Press, 1988), 141-68.

${ }^{76}$ Hassrick, The Sioux, 162.

${ }^{77}$ Loy and Hesketh, 'Competitive Play on the Plains', 82-3.

${ }^{78}$ Adolf Hungrywolf, The Blackfoot Papers - Volume One: Pikunni History and Culture (Skookumchuk: The Good Medicine Cultural Foundation, 2006), 16.

${ }^{79}$ Anthony McGinnis, Counting Coup and Cutting Horses: Intertribal Warfare on the Northern Plains, 1738-1889 (Lincoln: University of Nebraska Press, 1990), 11.

${ }^{80}$ Biolsi, 'Ecological and Cultural Factors in Plains Indian Warfare'; Cf. Ewers, The Horse in the Blackfoot Indian Culture, 239, for a further twist to this argument when he notes how 'some young [Blackfoot] men were both luckless and inveterate gamblers, who lost all their horses and were forced to return again and again to enemy camps to recoup their losses. Their love of gambling kept them poor and at the same time kept them active as horse raiders' (emphasis added).

${ }^{81}$ Captain Lorenzo Cooke, Acting Agent of the Blackfeet Reservation, Montana, as quoted by the United States Commissioner of Indian Affairs, Annual Report of the Commissioner of Indian Affairs, for the Year 1894 (Washington, DC: Office of Indian Affairs 1894), 159.

${ }^{82}$ Wilson, 'Report on the Blackfoot Tribes', 192.

${ }^{83}$ McGowan et al., 'Sacred and Secular Play in Gambling among Blackfoot Peoples of Southwest Alberta'.

${ }^{84}$ For example, Ewers, The Horse in the Blackfoot Indian Culture, 234.

${ }^{85}$ Stephen Dow Beckham, 'History since 1846' in Handbook of North American Indians Volume 12 Plateau, ed. Deward Walker (Washington, DC: Smithsonian Institution, 1998), 149-73.

${ }^{86}$ Loretta Fowler, 'Arapaho' in Handbook of North American Indians Volume 13 Great Plains Part 2, ed. Raymond DeMallie (Washington, DC: Smithsonian Institution, 2001), 840-62.

${ }^{87}$ Clyde Ellis, "“There is No Doubt...The Dances Should Be Curtailed": Indian Dances and Federal Policy on the Southern Plains, 1880-1930', Pacific Historical Review 70 (2001): 557, emphasis in the original text, which was written in 1914. ${ }^{88}$ Ibid. 558.

${ }^{89}$ Elisabeth Saunders, 'Pine Ridge Reservation Fairs: Building Intercultural Communities Through Play', James A. Rawley Graduate Conference in the 


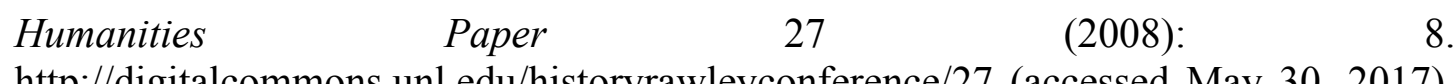
http://digitalcommons.unl.edu/historyrawleyconference/27 (accessed May 30, 2017). The Oglala were not alone: the Gros Ventre likewise made horse races a central part of their annual Hays Fair from the very beginning of the twentieth century, including races against the Assiniboin (Nakota), with whom they shared their small Fort Belknap reservation; see Loretta Fowler and Regina Flannery, 'Gros Ventre', in Handbook of North American Indians Volume 13 Great Plains Part 2, ed. Raymond DeMallie (Washington, DC: Smithsonian Institution, 2001), 677-94.

${ }^{90}$ Frederick Hoxie, Parading Through History: The Making of the Crow Nation in America 1805-1935 (Cambridge: Cambridge University Press, 1995), 363.

${ }^{91}$ Saunders, 'Pine Ridge Reservation Fairs', 9.

92 Ibid.

${ }^{93}$ Allison Fuss Mellis, Riding Buffaloes and Broncos: Rodeo and Native Traditions in the Northern Great Plains (Norman: University of Oklahoma Press, 2003), 49.

${ }^{94}$ Allison Fuss, 'Cowboys on the Reservation: The Growth of Rodeo as a Lakota National Pastime', South Dakota History 29 (1999): 211-28.

95 Ian Dyck, 'Does Rodeo Have Roots in Ancient Indian Traditions?', Plains Anthropologist 41 (1996): 205-19.

${ }^{96}$ McGowan et al., 'Sacred and Secular Play in Gambling among Blackfoot Peoples of Southwest Alberta', 248.

97 Ellis, 'There is No Doubt...The Dances Should Be Curtailed'; Saunders, 'Pine Ridge Reservation Fairs'.

${ }^{98}$ Fuss Mellis, Riding Buffaloes and Broncos, 19.

${ }^{99}$ Clark, They Sang for Horses, 310, who describes the Navajo dances as 'squaw dances', a term now understood by some as derogatory, but likely to be a reference to dances associated with Enemy Way (Ana'i Ndáa') ceremonies that traditionally counter the harmful effects of ghosts; see, Clyde Kluckholn, Dorothea Cross Leighton, Lucy Wales and Richard Kluckholn, The Navaho (Cambridge, MA: Harvard University Press, 1974), 228-9.

${ }^{100}$ Seifert, 'An Introduction to Contemporary Native American Horse Culture', 157. But see also Bethke, 'Dog Days to Horse Days', for the suggestion that its origins should be placed as early as the 1920 s.

101 'New Council to Oversee Indian Relay Racing', Seminole Tribune March 31, 2017, $\quad 3 \mathrm{C}, \quad \mathrm{http}: / /$ semtribe.com/STOF/docs/default-source/tribunearchive/2017/seminoletribune march31_2017.pdf?sfvrsn=b41f96ee 6 (accessed 22 January, 2019); PIHRA (Professional Indian Horse Racing Association) https://engb.facebook.com/pages/category/Education/Professional-Indian-Horse-Racing-

Association-476531622450149/(accessed January 18, 2019).

102 Jenni Whiteley, 'Eastern Idaho State Fair Adds All-Female Indian Relay Race', Idaho State Journal https://www.idahostatejournal.com/members/eastern-idaho-statefair-adds-all-female-indian-relay-race/article 08eae969-71d2-545e-a5ca-

6387e6d6e1b8.html (accessed August 9, 2018).

${ }^{103}$ Seifert, 'An Introduction to Contemporary Native American Horse Culture'.

104 HNIRC (Horse Nations Indian Relay Council)

http://www.horsenationsrelay.com/blog/ (accessed January 18, 2019).

${ }^{105}$ In this kind of start horses are lined up with their tails to the starting line and heads opposite the direction of the race so that they have to wheel around when the race begins. A nineteenth-century account can be found in Butler, 'Indian Horse Racing in Colorado', 31 . 
${ }^{106}$ Bethke, 'Dog Days to Horse Days', 339.

107 Ibid. 344-5; see also the film Indian Relay, directed by Charles Dye (2013; Bozeman, MT: KUSM-TV/Montana PBS and ITVS) http://www.pbs.org/independentlens/films/indian-relay/ (accessed January 22, 2019). ${ }^{108}$ Seifert, 'An Introduction to Contemporary Native American Horse Culture', 158.

${ }^{109}$ Hungrywolf, The Blackfoot Papers - Volume Two, 684.

${ }^{110}$ Seifert, 'An Introduction to Contemporary Native American Horse Culture', 158. Much the same combination of celebrating an equestrian warrior heritage, including the use of traditional religious practices such as praying in sweat lodges before a race and placing sacred eagle feathers on the horses taking part, marks the famous Suicide Race of the Omak Stampede, held annually in Washington State since 1935. This involves racing down a 70 metre-long steeply $\left(\sim 33^{\circ}\right)$ angled hill and then across the Okanogan River at its base before completing a near $500 \mathrm{~m}$ sprint to the local rodeo arena. Unsurprisingly, deaths and injuries to horses, if not to riders, are far from uncommon (Nick Timiraos, 'The Race Where Horses Die', Wall Street Journal, August 11, 2007, http://online.wsj.com/public/article/SB118678342614494614M49PZaSriaBsYASGQhdKeSlj5OU_20080810.html?mod=rss_free The Race Where Horses Die (accessed January 22, 2019).

${ }^{111}$ As well as Indian Relay, examples include Fast Horse, directed by Alexandra Lazarowich (2018; Edmonton, Canada; Handful of Films) https://handfuloffilms.ca/our-films/fast-horse/ (accessed October 28, 2019), and Equus: Story of the Horse, directed by Niobe Thompson (2019; Edmonton, Canada; Handful of Films) https://handfuloffilms.ca/our-films/equus-story-horse/ (accessed October 28, 2019).

${ }^{112}$ Catlin, Letters, 143.

${ }^{113}$ Ewers, The Horse in the Blackfoot Indian Culture, 235.

${ }^{114}$ See also, for example, Mike Huggins, Flat Racing and British Society, 1790-1914: A Social and Economic History (London: Frank Cass, 2000); Elizabeth Tobey, 'The Palio in Italian Renaissance Art, Thought, and Culture' (PhD diss., Graduate School, University of Maryland, 2005). Peter Edwards, Karl Enenkel, and Elspeth Graham, eds., The Horse as Cultural Icon: The Real and the Symbolic Horse in the Early Modern World (Leiden: Brill, 2012); 593-624; and Sinclair Bell, and Carolyn Willekes, 'Horse Racing and Chariot Racing', in The Oxford Handbook of Animals in Classical Thought and Life, ed. Gordon Campbell (Oxford: Oxford University Press, 2014), 478-90.

115 Elizabeth Atwood Lawrence, Hoofbeats and Society: Studies of Human-Horse Interactions (Bloomington: Indiana University Press, 1985); Bethke, 'Dog Days to Horse Days'; Seifert, 'An Introduction to Contemporary Native American Horse Culture', 147.

${ }^{116}$ Mitchell, Horse Nations.

${ }^{117}$ John Cooper, 'The Araucanians', in Handbook of South American Indians, Volume 2: The Andean Civilizations, ed. Julian Steward (Washington, DC: Smithsonian Institution, 1946), 687-760; George Musters, At Home with the Patagonians (London: John Murray, 1871); Alfred Métraux, 'Indians of the Gran Chaco', in Handbook of South American Indians, Volume 1: The Marginal Tribes, ed. Julian Steward (Washington, DC: Smithsonian Institution, 1946), 197-370; Kathryn Hunter, 'Rough Riding: Aboriginal Participation in Rodeos and Travelling Shows to the 1950s', Aboriginal History 32 (2008): 82-96; Carolyn Mincham, 'A Social and Cultural History of the New Zealand Horse' (PhD diss., School of Humanities, 
Massey University, Albany, New Zealand, 2008); Felipe Garay Méndez, 'El hacerse hombre en la Guerra: la construcción de las masculinidades en el caso de Bahía Portete' (Monografía de Grado, Escuela de Ciencias Humanas, Universidad del Rosario, Bogotá, 2014), 73.

118 Catlin, Letters and Notes on the Manners, Customs and Conditions of North American Indians, Volume One, 143.

\section{List of Figures}

Figure 1. Horse racing on a course behind a Mandan village in what is now Missouri 1832-1833 as depicted by George Catlin. Smithsonian American Art Museum 1985.66.432, Washington, DC (Source: Wikimedia Commons https://commons.wikimedia.org/wiki/File:George Catlin -

Horseracing_on a Course Behind the Mandan_Village - 1985.66.432_-

Smithsonian_American_Art_Museum.jpg (accessed January 22, 2019)).

Figure 2. Map of the Great Plains, Plateau, and Southwest of Canada and the United States, showing the approximate locations of Native peoples mentioned in the text $\mathrm{c}$. 1870. Note that the Piegan are not shown as they are a sub-division of the Blackfoot.

Figure 3. Horse racing of the Sioux near Fort Pierre (South Dakota) c. 1836 as depicted by Karl Bodmer (Maximilian von Wied, Travels in the Interior of North America 1832-1834, Volume 1, Plate 30 (Köln: Taschen GmbH, 2001) (Source: Wikimedia Commons reproduced under Creative Commons CC0 1.0 Universal Public Domain

Declaration https://en.wikipedia.org/wiki/File:Karl_Bodmer_Horse_Racing_of the Sioux_Sourc e).jpg (accessed January 22, 2019)).

Figure 4. Indian women racing on horseback at the Pendleton Round-Up, Umatilla County, Oregon, c. 1940, photographed by Ralph I. Gifford. (Oregon Multicultural Archives, Oregon State University Special Collections \& Archive Research Center P218-SG2 https://www.flickr.com/photos/osucommons/4987077826/in/photolist8AG5us-8AG2ys-YGgWdT-8ACYJX-r6xK7G-YMqESu-LgZsTY-Lh8RbB-Lh8G5v (accessed January 22, 2019)).

\section{List of Tables}

Table 1. Stimulant and restorative plants administered to Native American Plains horses (after Ewers The Horse in the Blackfoot Indian Culture; Morgan "Sugar Bowls" (Clematis hirsutissima): A Horse Restorative of the Nez Perce). 